\title{
PRESERVAÇÃO ANCESTRAL SILENCIOSA
}

\author{
Marcos Rodrigues ${ }^{1}$ \\ DOI 10.26512/revistacalundu.v4i1.30510
}

Resenha do livro: SOUSA JÚNIOR, Vilson Caetano de. Ijexá, o povo das águas. Recife: Ed. Liceu, 2019.

A leitura do livro Ijexá, o povo das águas, de Vilson Caetano de Sousa Júnior, confirma a ideia de que o conhecimento é uma fonte inesgotável, principalmente no âmbito das ciências humanas e sociais. O leitor menos informado que só olhar a capa pode imaginar que seja apenas mais uma publicação sobre candomblé. E, assim, estará perdendo a oportunidade de conhecer um dos elementos formadores da diáspora africana na Bahia: o povo Ijexá. Um trabalho investigativo que traz importantes informações sobre etnicidades, memória, resistência e legado cultural, além de ampliar a visibilidade sobre as nações de candomblé a partir de uma preservação silenciosa da ancestralidade.

O autor apresenta um discurso próprio de quem transita no segmento dos estudos afro-brasileiros, dialogando com outros pesquisadores, antigos e contemporâneos, para fundamentar a busca da existência subjetiva da comunidade Ijexá no universo do candomblé da Bahia. O texto agradável possui uma narrativa dinâmica, sem linguagem rebuscada, beirando o humor em várias passagens, o que garante a fluidez da leitura. Surpresa maior é a série de revelações trazidas ao conhecimento do leitor, especialmente a de que Ijexá não é apenas um ritmo musical ou um toque religioso, como ficou convencionado pelo senso comum. Por isso, a leitura do livro deve ampliar o horizonte das relações étnicas e da história do candomblé na Bahia.

Antes, vale dizer que o texto desperta o leitor pelo leque de curiosidades e o conduz até o fim, apesar de ter seus objetivos bem definidos e alcançados.

Vilson Caetano de Sousa Júnior, professor da UFBA, pesquisador da área de antropologia, autor de vários livros sobre relações étnico-raciais e alimentação, é da nova geração intelectual mais atenta à sua comunidade na diáspora africana, tornando-a objeto de investigação para falar dos seus com propriedade, sem o olhar forasteiro.

\footnotetext{
${ }^{1}$ Universidade Federal da Bahia - UFBA. E-mail. jmbr@bol.com.br
} 
Em Salvador, três encontros de nações de candomblé foram realizados e em nenhum deles a cultura Ijexá apareceu como elemento formador da religiosidade afrobrasileira na Bahia. Entretanto, a partir de um laudo antropológico elaborado para respaldar o pedido de tombamento de um terreiro, o livro traz à luz o mapeamento do grupo étnico reconhecido como Ijexá na cidade e a história do Ilê Axé Kalé Bokun, que se desdobra na história de vida do seu fundador Severiano Santana Porto.

Categórico ao abordar a presença do povo das águas na Bahia, Sousa Júnior abre um novo caminho sobre as questões que envolvem as relações identitárias entre as nações de candomblé. $\mathrm{O}$ recurso a algumas citações sutis faz compreender a existência da cultura Ijexá nesse universo, tendo em vista a sua significativa contribuição. Seguir os passos do pesquisador, na coleta de dados sobre a trajetória do terreiro e da história de vida de Severiano Porto, facilita obter a noção do reparo histórico da cidade através do ofício antropológico.

Se não fosse o crime da escravidão sobre os nossos, trabalhos como esse talvez não se fizessem necessários para reconhecer quem é quem na negritude e no candomblé da Bahia. O livro apresenta a marca do deslocamento entre grupos africanos na diáspora que buscavam escapar dos atos de perseguição da política colonial. Dividido em cinco momentos, conforme relata, como um quebra-cabeça, o cruzamento de informações, o trabalho de investigação foi gerando fatos, lembranças, histórias de vida, a história de um terreiro e a força de uma tradição religiosa mantida até então no plano da invisibilidade.

A comunidade do terreiro surge no fim do século XIX, no bairro de Plataforma, atualmente na região do subúrbio ferroviário, cujo acesso só era possível de barco pela Península de Itapagipe. Observar o local daquele tempo com os olhos de hoje possibilita imaginar a dificuldade de circulação entre alguns bairros da periferia de Salvador. Era o tempo da pequena cabotagem que compunha o cenário da Baía de Todos os Santos, com o trânsito de pessoas em alvarengas e o transporte de produtos comerciais em saveiros. É parte desse tempo heroico vivido por nossos antepassados que o autor conta no livro.

Assim, a narrativa se estende às estratégias de deslocamento do grupo Ijexá para garantir a preservação da sua cultura religiosa e chega aos fragmentos da trajetória do fundador do Ilê Axé Kalé Bokun. O trabalho preenche uma lacuna importante nos estudos étnicos e entre as comunidades de terreiro. E um dos seus méritos está na abordagem sobre a atuação do grupo em estudo nos bairros periféricos da cidade baixa. 
É mais uma luz que se acende sobre a escuridão do nosso passado cuja memória não sai do controle da escravidão e suas vertentes contemporâneas.

As discussões no meio acadêmico e nas comunidades de terreiro certamente cresceram com esta publicação que adentra um território ainda pouco explorado pelos estudos afro-brasileiros. O relato descortina os rastos das lideranças religiosas de um núcleo de africanos residentes no centro de Salvador, como prefere denominar o autor, com suas estratégias para garantir sua preservação. $O$ estudo expõe dados que certamente cruzam com a história de outras casas e lideranças já conhecidas em outras pesquisas realizadas, conforme ressalta na revisão bibliográfica.

O grupo Ijexá já exercia a sua mobilidade urbana em Salvador. A narrativa demonstra o rigor da investigação realizada em subidas e descidas, entradas e saídas, idas e vindas, achados e perdidos, uniões e separações, com a força das entrevistas, as buscas em arquivos e cartórios e outras ferramentas do trabalho de campo. Assim, no exercício da escrita, Sousa Júnior prende o leitor à medida que fornece curiosidades e dados preciosos sobre essa resistência identitária que transita na mística do território de uma cidade cercada e minada pelas águas.

Outro aspecto interessante do livro é o de ordem iconográfica. As imagens reproduzidas contribuem amplamente para o reconhecimento de elementos étnicos, símbolos religiosos, instrumentos musicais, meios de transporte, lugares, documentos e pessoas que fizeram e fazem a história do candomblé da Bahia. Algumas imagens apresentam uma cidade distante e estranha, porém muito familiar aos olhos de quem conheceu um pouco da antiga Salvador ou ouviu histórias dos seus mais velhos. O letramento é importante, mas a imagem quando aparece abre um caminho de memória e imaginação infinito.

O candomblé agora tem mais uma nação marcada pela resistência e reconhecida após a publicação desse livro sobre o povo das águas. É um trabalho que desvenda a existência da identidade Ijexá como origem étnica, o perfil do orixá Logun-Edé, o perfil do babalorixá Severiano Santana Porto e a história do Ilê Axé Kalé Bokun. O autor mistura suas habilidades de religioso, intelectual e pesquisador para dar conta de uma etnografia ainda por ser escrita a respeito da história do candomblé. Entre outros destaques do livro está a identificação do terreiro como secular, tão antigo quanto aqueles considerados os primeiros de que se tem notícia. 
A publicação de Ijexá, o povo das águas oferece grande contribuição aos estudos étnicos e suas afinidades com a antropologia, a história, o urbanismo, a religião, a oralidade e a memória. $\mathrm{O}$ autor coloca em foco o grupo Ijexá como protagonista na formação do candomblé, que, apesar de atuar sutilmente e de forma significativa, ainda não fora percebido nos estudos afro-brasileiros. Após a leitura de cada momento (capítulo) do livro, é possível fechar os olhos e imaginar a cidade de Salvador como um caldeirão de culturas segregadas em permanente ebulição, cujos elementos da etnicidade se apresentam em mais um exemplo de ação e experiência na diáspora africana.

Recebido em: 04/03/2020

Aceito em: $22 / 04 / 2020$ 